\title{
SOBRE DOS FRAGMENTOS CERÁMICOS IBÉRICOS DE LA ALCUDIA DECORADOS CON ROSTROS FRONTALES
}

\author{
RAFAEL RAMOS FERNÁNDEZ \\ Museo Arqueológico de Elche
}

\begin{abstract}
Este trabajo plantea la publicación de dos fragmentos cerámicos decorados con rostros frontales como imagen de una diosa local de carácter fúnebre, que amplían el conocimiento iconográfico en lo referente a las representaciones de las divinidades iberas y a las relaciones alegóricas que permitieron asociarlas con las imágenes que debían manifestarlas y permitían identificarlas. Por ello, debe considerarse que una de las formas esenciales de representación simbólica es la máscara, puesto que aquella es resultado de la ocultación de una metamorfosis y responde a un significado diferenciable de lo que en ella se había figurado.

This work raises the publication of two ceramic fragments decorated with frontal faces like an image of a local godness of funeral nature, that amplify the iconographic knowledge about the iberian godness representations and the alegoric relationhips that allow asociate then with the images that must manifest and identify them. There must be considered that one of the esential way of symbolic representation is the mask, because it is the result of the concealing of a metamorphosis and answers to a differential sense that it is represented by itself.
\end{abstract}

La presentación de dos fragmentos inéditos de cerámica ibérica pintada, existentes en el Museo Monográfico de La Alcudia, motiva esta información especialmente interesante por el tema representado en ellos.

La cerámica ibérica de «tipo Elche» supuso una producción local, realizada a lo largo de los siglos II y I a.J.C., consistente en una manufactura artesanal caracterizada por su ornamentación pintada, constituida por temas figurativos desarrollados en el interior de marcos que generalmente los delimitan, pues en estos recipientes cerámicos las zonas de las asas marcan los límites verticales de los paneles decorados que, horizontalmente, quedan encuadrados por esquematizaciones de serpientes plasmadas como bandas de SSS o por simples líneas con el sentido de separación de pisos ideales.

Los motivos fundamentalmente pintados en este tipo cerámico expresan la figuración del surgimiento 


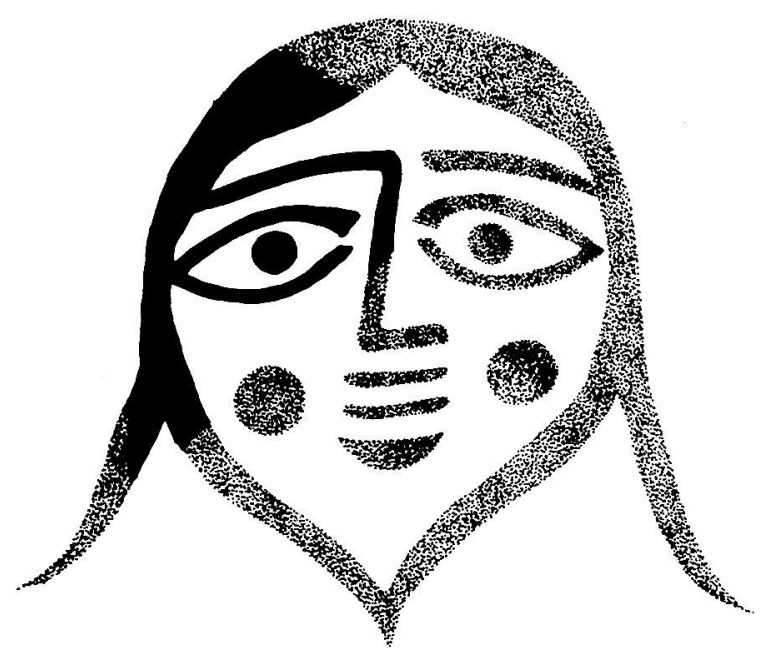

de la vida asociado a la representación de una divinidad femenina que se muestra bien como efigie o bien como rostro que brota de la tierra, imágenes que pueden aludir a una divinidad local ctónia que si se la relaciona con figuras de diosas del ámbito griego puede identificarse con representaciones del círculo de Demeter y si se la vincula al mundo púnico, que pudo ser quien a través del comercio difundiera esta iconografía en sus áreas de influencia, deberían identificarse con Tanit; aunque esas identificaciones no implican más que relaciones de tipo formal que tal vez provocaran el revestimiento de una idea preexistente asociada a un culto autóctono de carácter fúnebre imbricado a las corrientes religiosas imperantes en el Mediterráneo Occidental, si bien no debe tenderse a establecer un paralelo con las formas de mito y de rito griegas que esta cerámica sugiera en función de su temática, sino a tratar de precisar que los iberos pudieron dar un mismo sentido a su expresión religiosa.

Las piezas que ahora se incorporan al conjunto temático con representación de rostros frontales son las siguientes:

1.- Fragmento cerámico de $5 \mathrm{~mm}$. de grosor, de pasta marrón clara y superficie exterior lavada, decorada con parte de un rostro frontal pintado, del que se conserva un tercio que contiene un ojo, la ceja y parte de la nariz, su contorno y el arranque de una trenza. Su estilo pictórico es relacionable con el de la representación realizada en el calatos hoy llamado «La Tonta del Bote» (RAMOS FOLQUES, 1955, 122; y acuerdo del IV C.A. S.E.).

2.- Fragmento cerámico de $8 \mathrm{~mm}$. de grosor, de pasta marrón clara y superficie exterior lavada, deco-

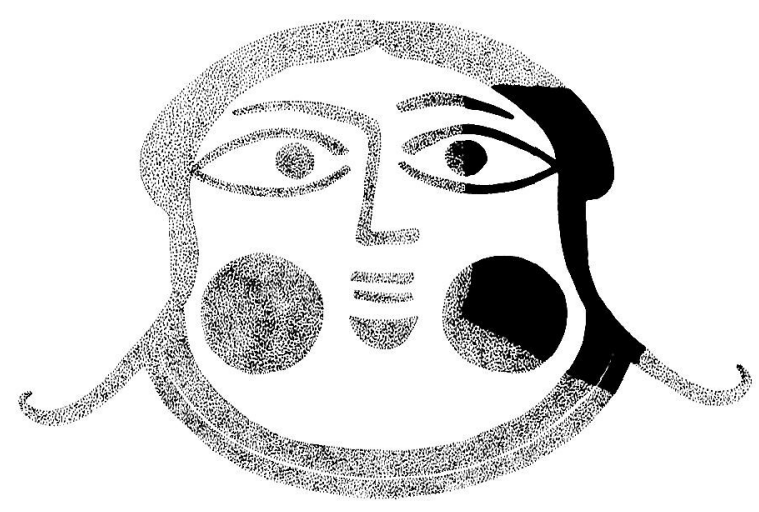

rada con una mitad de un rostro frontal pintado, del que se conserva un ojo y su ceja, parte del colorete circular o arrebol de la mejilla, el detalle lateral del peinado y, tal vez, parte de los collares que engalanaban su cuello. La realización pictórica ofrece un nuevo diseño gorgónico que se suma a los representados en este tipo de cerámica ibérica ya conocidos.

Durante estos últimos años se han iniciado estudios referidos a las distintas maneras de simbolizar lo divino en las obras plásticas, investigaciones tendentes a conocer cómo representaron los iberos a sus divinidades y cuáles fueron las relaciones alegóricas que permitieron a aquellos iniciados en los cultos asociar a su diosa con la imagen que debía manifestarla y permitía identificarla (RAMOS FERNANDEZ, 1991).

Todo símbolo, como imagen de algo que no se quiere o no se puede expresar directamente, es una muestra que contiene una significación especial puesto que alude al camino que conduce desde nuestro mundo mortal hasta el espacio de lo imperecedero, porque hace referencia a la eterna polaridad existente entre la vida y la muerte. Por ello su motivación radica en la voluntad humana de expresar lo que es propiamente inexplicable. El símbolo, que en cuanto idea se identifica con deseo y evocación, pasa a ser realidad cuando se le confiere la facultad de realizar acciones mágicas, cuando se le considera capaz de afectar directamente el curso de los acontecimientos, porque el símbolo retrata la realidad antes de que esa realidad llegue a existir (GIEDION, 1981, 540) y, por ello, una de las formas esenciales de expresión simbólica es la máscara, que si por una parte implica fingimiento y disfraz, por otra se integra plenamente en el 


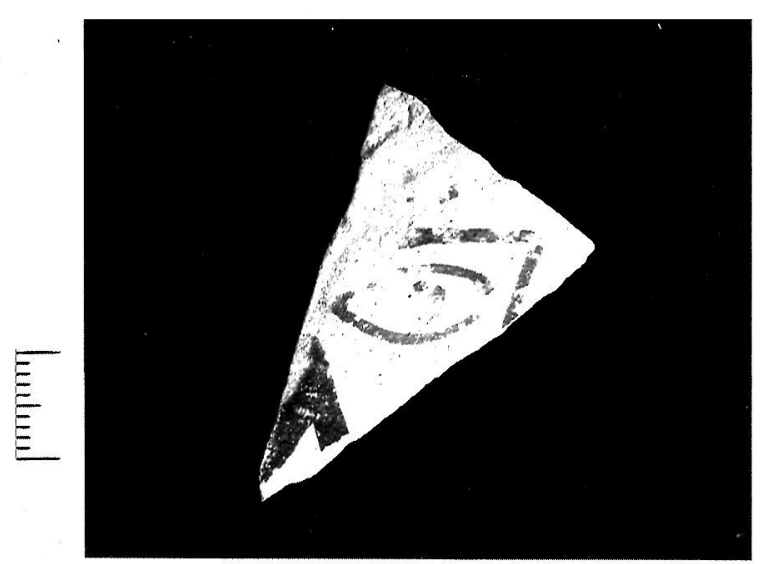

1

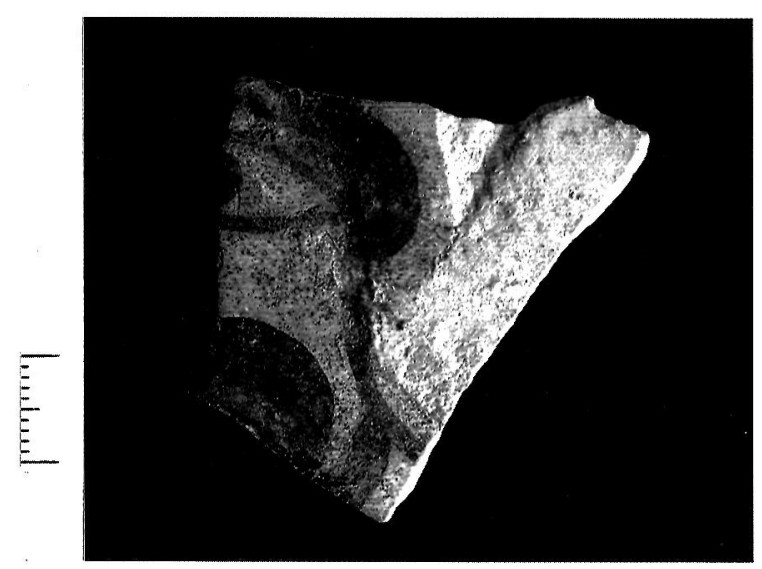

2

ámbito de lo existente y de lo real porque forma parte de las representaciones cosmogónicas. Por eso las transformaciones que refleja no son mera apariencia sino manifestación de algo verdadero puesto que la creación de seres inexistentes en la naturaleza responde a un deseo de contacto con potencias imprevisibles. Así, las máscaras contienen una interpretación íntima de lo posible y lo fantástico y no se someten a una identidad concreta, para su comprensión es necesario admitir el factor de la imprecisión, pues la vacilación entre lo real y lo imaginario constituye su auténtica personalidad.

El estudio de estas representaciones de máscaras hace ineludible recurrir a las referencias de representaciones griegas de diosas (RAMOS FERNANDEZ, 1992, 95-97) que fueron expresión de potencias femeninas del más allá, de fuerzas distintas paro hilvanadas por su acomodación a la esfera infernal que, quizás por ello, idealizaron su imagen con la carátula que guardaba relación, según sus propias modalidades, con la alteridad (VERNANT, 1986, 15-106), reflejo de la experiencia de los griegos con el otro bajo las formas que ellos le atribuyeron. Así, la máscara deforme expresa la alteridad extrema, el miedo a lo que es radicalmente distinto, porque para los humanos supone encontrar la muerte.

No obstante, no debe extrañar el aspecto gorgónico de las máscaras representadas en este tipo cerámico si se recuerda que el mítico Geryón tartésico («el mugiente» - el toro), según Hesíodo (Teogonía, 274) era nieto de Medusa y Poseidón, por lo que aquella era también engendradora de la estirpe ibérica; además de que Geryón había nacido en una cueva de la montaña de plata «casi enfrente de la ilustre Erytheia» (Estrabón, 148), la isla del ocaso, del Oeste, la tierra de la niebla (Hesíodo: Teogonía, 294), la mansión estigia sustentada sobre columnas de plata (Hesíodo: Teogonía, 779); y de que las Gorgonas «están en el Océano, cerca de la ciudad de Tartessos de Iberia» (Licofron, 838). Mitos que posiblemente conocieran los iberos y que por ello plasmaran imágenes relacionables con las ideas que los textos citados sugieren.

Pero esos rostros que configuran las máscaras, terribles y burlescos a la vez, como símbolos en sí, esconden un significado ideal y revisten una belleza interior que, por ellos, queda protegida y oculta.

Toda transformación lleva consigo una circunstancia misteriosa y también confusa porque lo equívoco y lo ambiguo se originan en el mismo instante en que algo se modifica lo suficiente para ser considerado otra cosa aunque aún siga siendo lo que era. Por ello la máscara es el resultado de la ocultación de una metamorfosis, ya que ese encubrimiento abre el camino al cambio y propicia el tránsito mágico entre lo que se es y lo que se va a ser. Así, la imagen que constituye la máscara responde a un significado simbólico distinto a lo que en ella se ha figurado.

Las máscaras contienen dos características constantes que condicionan las representaciones de sus rostros: la frontalidad y la deformidad. Siempre se muestran frontales porque siempre se enfrentan a quienes las contemplan. Su apariencia refleja un gesto peculiar que, producto de la perturbación del aspecto antropomorfo, origina un semblante que vincula lo alucinante y lo caricaturesco, pues se muestran como el revés lúgubre, la cara oscura, de la Gran Diosa.

Por ello, ante las obras pictóricas mencionadas, parece posible que los iberos crearan la imagen simbóli- 
ca de una potencia ctonia, rostro que al fundir la frontalidad con la deformidad originó una expresión identificable con la divinidad emblematizada por la máscara, porque así manifestaban la diferenciación existente entre las representaciones de la diosa y las de los humanos.

\section{BIBLIOGRAFÍA}

GIEDION, S., 1981: El presente eterno: los comienzos del arte, Madrid, 540-544.

OLMOS ROMERA, R., 1992 a: «El surgimiento de la imagen en la sociedad ibérica», La sociedad ibérica a través de la imagen, Barcelona, 8-32.
— 1992 b: «Originalidad y estímulos mediterráneos en la cerámica ibérica: el ejemplo de Elche», Lucentum, VII- VIII, Alicante, 79-102.

RAMOS FERNANDEZ, R., 1989: «Nuevos hallazgos en La Alcudia», AESPA 62 Madrid, 236-240.

- 1991 a: Simbología de la cerámica ibérica, Elche, 1-96

- 1991 b: «Anodos y símbolos de la cerámica ibérica' Madrid, 9 , 95-96.

- 1992 a: Consideraciones sobre la temática pintada en la cerámica ibérica de Elche», Annali della Facoltá di Lettere XXVI (nuova serie XII, 1988/1989) Studi Classici, Perugia, 171- 190 - 1992 b: «La crátera iberorromana de La Alcudia», Estudios de Arqueología Ibérica y Romana, Trabajos Varios 89, Valencia, 175-190.

1992 c: «La máscara de la diosa en la cerámica ibérica», Madrid, 20, 95-97.

RAMOS FOLQUES, A., 1955: «Excavaciones en La Alcudia. 1940-1948», NAH, II. 1-3, Madrid, 122.

VERNANT, J.P., 1986: La muerte en los ojos, Barcelona, 15- 106. 